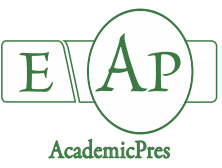

Caliskan O et al. (2020)

Notulae Botanicae Horti Agrobotanici Cluj-Napoca 48(1):245-260

DOI:10.15835/nbha48111753

Research Article

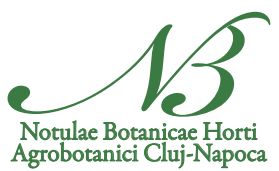

\title{
Agronomic characteristics of Serapias vomeracea (Burm. f.) Briq. salep orchids
}

\section{Omer CALISKAN ${ }^{1}$, Dursun KURT ${ }^{1 *}$, Mehmet Serhat ODABAS ${ }^{2}$}

\author{
${ }^{1}$ Ondokuz Mayis University, Bafra Vocational School, Department of Plant and Animal Production Samsun, \\ Turkey; ocaliskan@omu.edu.tr (*correspondingauthor);dursunkurtt@gmail.com \\ 20ndokuz Mayis University, Faculty of Agriculture, Department of Field Crops, Samsun, Turkey; msodabas@gmail.com
}

\begin{abstract}
Although salep orchids are annual plants, each new generation emerges larger than their parents. There are no data on the developmental performance of these species that cannot be cultivated due to production difficulties. This study discusses Salep vomeracea (Burm. f.) Briq., one of the most common species in temperate climate regions. Tubers obtained from natural flora were divided into seven groups according to their size. Morphological characteristics of the seedlings developed from these tubers were determined and observed up to the harvest stage. The study was carried out in a randomized plot design with three replications and for two years. As a result of statistical analysis, all parameters were found to be significant. The canonical correlation between the first pair of canonical variables was $0.995(\mathrm{p}<0.01)$. The data obtained from the length of the planted tuber made the biggest contribution to the explanatory power of the canonical variables. Additionally, the mathematical relationship between width, height and area values of salep leaves was determined.
\end{abstract}

Keywords: canonical correlation; modeling; morphology; multivariate; yield

\section{Introduction}

The species belonging to the family Orchidaceae are very diverse in their habitats and physical dimensions. Most species of terrestrial orchids are distributed in the mid-latitude climates. These species have tuber, root or rhizome structures below the soil. Tuberous species are named and used as salep orchids (Bulpitt, 2005; Jalal et al., 2008; Hossain, 2011; Pant, 2013; Attri, 2016). They are recommended for various conditions such as infertility, miscarriage, tuberculosis, stomach problems, skin irritation, influenza in women in Europe. In the 18th and 19th centuries, they were among the supplies of the British army, used as a nutritious food for sick soldiers when dietary food and provisions were reduced. Prior to the spread of coffee and tea, it was known to be a beverage commonly used in the Middle East, England and Germany (Jagdale et al., 2009; Faraji et al., 2013; Turgay and Cinar, 2017). Famous medical doctor Avicenna mentions the use of salep in pastes utilized as aphrodisiac, appetite stimulant, phlegm reducer, cure for paralysis, stimulant for a clear mind, suppressor for desires and refreshers. Salep orchids with hundreds of species grow in many areas in Eastern Europe such as Afghanistan, Bukhara and India, and they are all used to produce salep (Kasparek and Grim, 1999; Kreutz, 2002; Hossain, 2011; Tatiya et al., 2018). Salep used to be sold as a drug in pharmacies in Turkey until around 50 years ago (Yaman, 2013).

Received: 15 Dec 2019. Received in revised form: 08 Jan 2020. Accepted: 18 Mar 2020. Published online: 31 Mar 2020. 
Salep has been among the natural resources that are freely collected and sold throughout the world until the last 20-25 years. Despite the increase in consumption of salep species that can not be produced gradually began to disappear (Molnar et al., 2017). Intense pressure for harvest has led to a reduction and genetic erosion in the salep populations. Many countries have moved to take measures to preserve biodiversity in their territories and pass them on to future generations. As with many living species, measures are taken and laws are put into effect for salep orchids with national laws and international agreements (Caliskan and Kurt, 2019a). Salep orchids are included in the Annex II of "The Convention on International Trade in Endangered Species of Wild Fauna and Flora (CITES)". Collection from nature and trade of salep orchids is prohibited. In all countries that have signed the CITES convention, those who collect orchid orchids are subject to severe fines (Swarts and Dixon, 2009; Gorbani et al., 2014).

Salep orchids are annual plants. The main reason why salep orchids cannot be produced is the microscopic seeds. Orchid seeds without endosperm cannot germinate under normal conditions (Swarts and Dixon, 2009; Bektas et al., 2013; Utami et al., 2017). Salep orchid produces a single tuber and this tuber has a single growth point. This prevents vegetative propagation as well. Seeds scattered in the natural environment can germinate when they can establish a symbiotic partnership with some mycorrhizae in the soil (Ponert et al., 2011; Warghat et al., 2014; Ong, 2016; Cig et al., 2018). In the first year, germinating seed can produce a few small leaves and a tiny tuber weighing less than one gram. When this newly formed tuber is planted, it produces a larger tuber and completes its vegetation and the process continues in the following years (Caliskan and Kurt, $2019 \mathrm{~b}$ ). However, due to the aforementioned production constraints, it is not known how big a tuber can be produced from the planted tuber and or what the upper limit of the progressive cycle is.

In scientific studies, data relating to a large number of related (dependent) or unrelated (independent) properties called variables are obtained from the samples examined. The fact that use of univariate statistical approaches is much preferred by researchers, especially because their results are easily interpretable in data sets whose effects are interrelated and variables are related in such a way often prevents the uncovering of hidden information between variables (Saglam, 2013). Therefore, multivariate analysis techniques have come to the forefront in determining the relationships between two or more sets of variables in terms of research being healthy and reliable (Cankaya et al., 2009). Although there is no obligation in this method, one of the variable sets can be considered as dependent and the other as independent variable set. In analysis, new variables are obtained from the linear compositions of the variables contained in each set. These new variables are called canonical variables and the correlation between these new variables is intended to be maximum (Keskin et al., 2005; Ozcomak et al., 2012). Canonical correlation analysis examines the relationship between two sets of random variables consisting of a large number of variables (Albayrak, 2006). In plant and animal breeding studies, it is necessary to carry out such studies in order to reveal the relationship structure between the early identified characteristics and the late identified and economically important characteristics without disturbing the integrity between the characteristics, and to be able to direct selection studies accordingly (Keskin et al., 2005).

Mathematical models obtained by multiple regression analysis are used to determine the relationship between two or more variables with cause-effect relationship and make predictions using this relationship (Odabas et al., 2010). In these mathematical models, variables must be divided into two groups as dependent variables and independent variables. A dependent variable is a variable that is tried to be explained by independent variables. These models are used for making predictions in various disciplines such as medicine, engineering, agriculture, economics, business, etc. (Odabas et al., 2014).

The Serapias vomeracea (Burm. f.) Briq. (S. vomeracea) species used in this study, spread wide across in temperate climate regions. They are found in the natural flora of Central Asia Mediterranean Basin and the coast of North Africa. Its range extends from the Azores and the Canaries in the west to the Caucasus in the east (Belusci et al., 2008; Pellegrino et al., 2005; Brullo et al., 2014; Velnuis et al., 2017). This species is one of the most widespread tuberous orchids in Turkey. Thus, it is easily accessible in many cities and regions. Ease of 
accessibility in the environment and the economic value of its tubers make S. vomeracea one of the most collected orchid species from its native habitats (Acemi and Ozen, 2019; Acemi et al., 2019). As with all orchid species, there is very little data about the development of tuber, new tuber yield and differences in plant characteristics regarding $S$. vomeracea. In this study, the development performance of $S$. vomeracea seedlings, which were selected as seeds and grouped according to their size, was intended to be examined for a period of two years. Canonical correlation analysis was used to explain whether there was a relationship between the parameters examined and the relationship between the two sets of variables in terms of the phases in which they were taken, and their contributions to variance. Leaf area prediction modeling was performed for $S$. vomeracea by applying multiple regression analysis to leaf characteristics.

\section{Materials and Methods}

\section{Materials}

The trial material $S$. vomeracea seedlings, were collected from the pasture areas in city of Samsun in December of 2017 as part of the "Investigation of Sustainable Agriculture Opportunities in Serapias Species Salep Orchids" project (PYO.BMY.1901.18.001). S. vomeracea species are of a reddish color with darker streaks on stems and flowers. The stem is thick and upright. The leaves are thin, lanceolate, channeled and divided in the middle. There are very few flowers on the inflorescence. The flower base leaflets (bract) are ovoidlanceolate or elongated. The tips of the bracts are pointed and they are covered stripes. The flowers are mediumsized, with reddish brown color. The tips of the petals and sepals are pointed. The central petal is heart-shaped and has white hairs (Renz and Taubenheim, 1984; Kreutz, 2009). Study material was created by dividing 63 individuals belonging to the genus into 7 groups with 9 individuals in each group according to their developmental status, and the visual, featuring two individuals from each group as their representatives, was presented in Figure 1. Such a classification was made since the limits of the vegetative parts are controlled by the size of the main tuber in salep orchids. In other words, every tuber planted continues its generation by creating a tuber slightly larger than itself (Caliskan and Kurt, 2019; Caliskan et al., 2019).

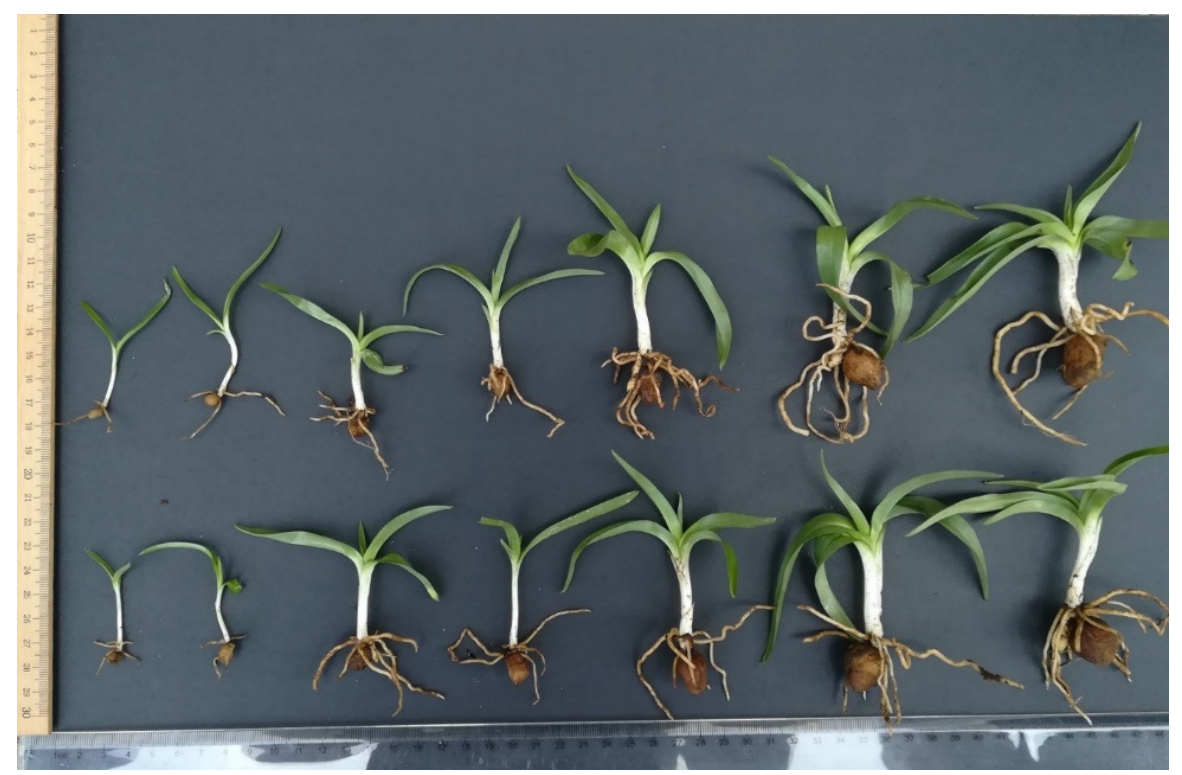

Figure 1. S. vomeracea seedlings examples which were divided into seven classes according to their biomass size 


\section{Methods}

The research was carried out in the experimental area of Ondokuz Mayıs University Bafra Campus in 2018-2019, with three replications. Average seedling length, tuber width and tuber length measurements of seedlings are given in Table 2. Seedlings seen in Figure 1 were filled with peat, whose chemical and physical properties were presented in Table 1, and planted in pots $15 \mathrm{~cm}$ in diameter on December 15, 2017, and left to their natural process. Vegetation was terminated on May 20, 2018 (Figure 2), and the mean values of plant height, tuber width, tuber length, tuber fresh weight, tuber dry weight, number of leaves, leaf width and leaf length taken on this date are given in Table 3. In the second year of the study, the procedures carried out in the previous year for the seedlings of $S$. vomeracea species obtained from the same location on 13 December 2018 were repeated. The second year vegetation of the study was terminated on May 16, 2019.

Table 1. Main chemical and physical properties and average amount of added nutrients for peat tested

\begin{tabular}{|c|c|c|c|c|}
\hline Chemical data & $\begin{array}{l}\text { Average amount of } \\
\text { added nutrients }\end{array}$ & \multicolumn{3}{|c|}{ Physical properties } \\
\hline $\mathrm{PH}$ range $\left(\mathrm{H}_{2} \mathrm{O}\right): 5.5-6.0$ & Nitrogen (mg N / I): 210 & $<10$ & $80-85$ & $5-10$ \\
\hline Fertilizer (g / l): 1.5 & Phosphorus $\left(\mathrm{mg} \mathrm{P}_{2} \mathrm{O}_{5} / \mathrm{I}\right): 240$ & 20 & 60 & $y \alpha \alpha$ \\
\hline Black sphagnum peat: $30 \%$ & Potassium $\left(\mathrm{mg} \mathrm{K}_{2} \mathrm{O} / \mathrm{I}\right): 270$ & & & \\
\hline White sphagnum peat: $70 \%$ & Magnesium (mg Mg / I): 100 & Dory matter & 口Water capacity & 口Air capacity \\
\hline
\end{tabular}

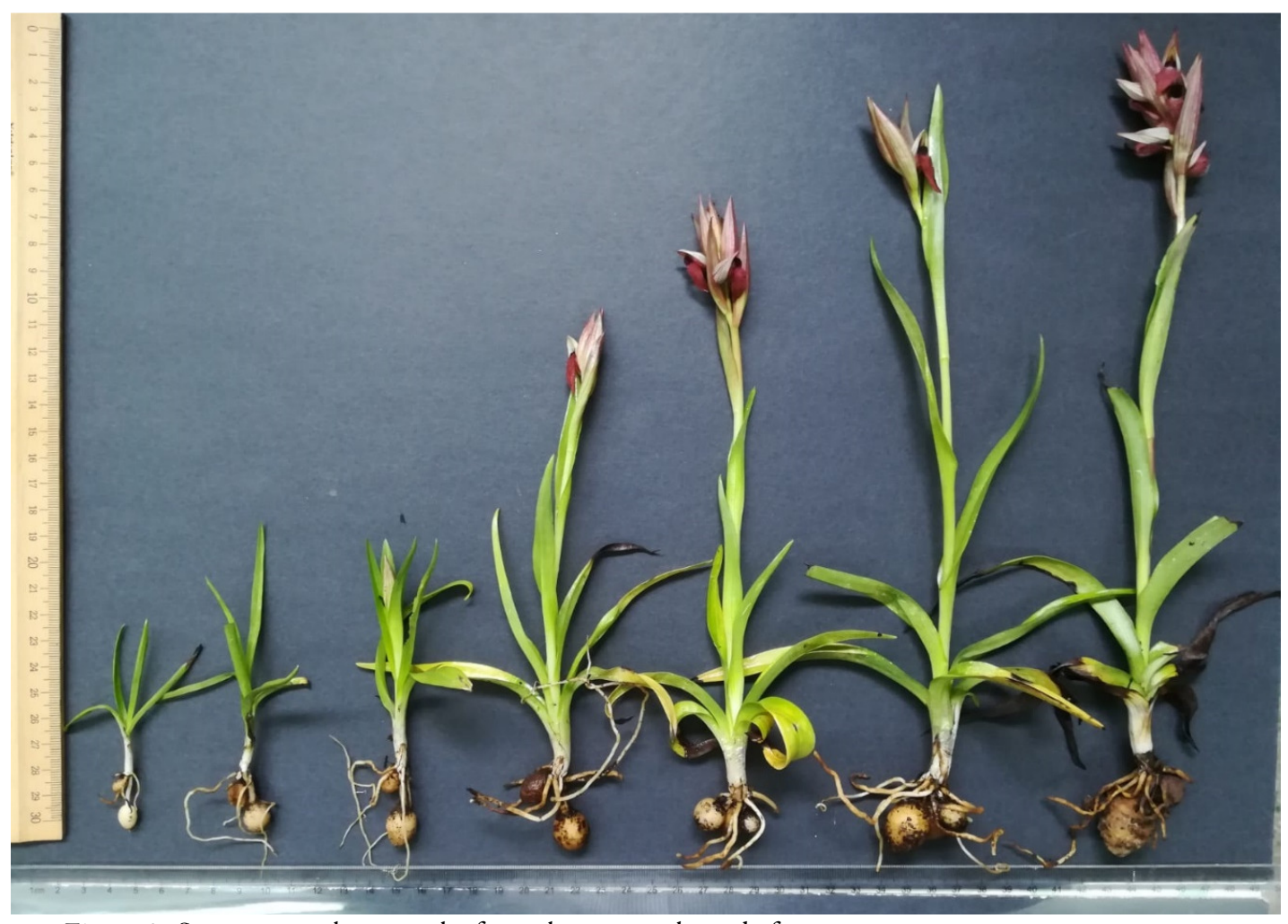

Figure 2.S. vomeracea plant samples for each group at the end of vegetation 
The data obtained from the study were subjected to variance analysis according to randomized block design, and two-year averages were interpreted with Duncan's multiple comparison test. SPSS software package was used for the evaluation of all data.

In the simplest correlation analysis known in statistics, the relationship between two variables $\left(Y_{i}, X_{i}\right.$ $i=1,2, \ldots n)$ is determined by simple correlation coefficient. The relationship between a dependent variable $(Y)$ and more than one independent variable $\left(X_{1}, X_{2}, \ldots X_{n}\right)$ is examined by multiple correlation analysis and by calculating partial correlations. In CCA, the most complex relationship analysis, the relationship between two sets of data $\left(X: X_{1}, X_{2}, \ldots X_{p}\right.$ and $\left.Y: Y_{1}, Y_{2}, \ldots Y_{q}\right)$, each containing more than one variable, is investigated with the help of correlations between the linear components selected from these two sets (Temurtas, 2016). CCA is applied to determine the correlation between linear combinations of variables in one set of variables $(X$ variable set, $q \times 1)$ called the canonical variable $V$ and linear combinations of variables in another set of variables ( $Y$ variable set, $p x 1$ ) called the canonical variable $U$ (Gunderson and Muirhead, 1997). In order to reflect the relationship between measurements taken at the time of planting and harvesting of Orchis purpurea Huds. seedlings, canonical variables $(U$ and $V)$ are created in such a form that canonical variable pairs $\left(U_{i} V_{i}\right)$ are independent of each other, and the estimated canonical correlation coefficient $\left(r_{i}\right)$ between the first canonical variable pair $\left(U_{I} V_{I}\right)$ is maximum (Johnson and Wicherm, 2002). While canonical variables are explained as symbols $U_{i}=Y a_{i}$ and $V_{i}=X b_{i}$, the coefficients $a_{i}$ and $b_{i}$ in the equation are standardized canonical coefficients of $p x I$ and $q x I$, respectively (Bilgin et al., 2003). In order for canonical correlation analysis to be performed, some assumptions must be met in the data set. These assumptions can be summarized as the properties showing normal distribution with multiple variables and the absence of multicollinearity between the properties, and the sample width being 5 times the number of variables in terms of reliability according to the results obtained (Keskin et al., 2005). The canonical correlation coefficient, which is a measure of the relationship between $X$ and $Y$ variable sets, is estimated by the following equation (Cankaya et al., 2009):

$$
P u_{1} v 1=r_{i}=\sqrt{\lambda_{i}}=\frac{\operatorname{Cov}(U, V)}{\sqrt{\operatorname{Var}(U) \operatorname{Var}(V)}}=\frac{a^{\prime} \sum_{12} b}{\sqrt{\left(a^{\prime} \sum_{11} a\right)\left(b^{\prime} \sum_{22} b\right)}} ; i=1,2, \ldots, p
$$

When multiple independent variables that affect the dependent variable are encountered, multiple linear regression analysis is used to determine the relationship between the dependent variable and independent variables. Multiple linear regression analysis examines which independent variable or variables have significant effect on dependent variable. In statistics, the multiple linear regression model is expressed mathematically as follows.

$$
Y=\beta_{0}+\beta_{1} X_{1}+\beta_{2} X_{2}+\cdots+\beta_{p} X_{p}+\varepsilon
$$

Here, $\mathrm{Y}$ is a dependent variable while $\mathrm{X}$ is an independent variable. The number of variables is $\mathrm{p}$ and the parameter values are $\beta_{j}(j=1,2, \ldots, p)$.

In the multiple linear regression analysis, how much of the change in the dependent variable is explained by the explanatory variables is determined by the coefficient of determination $\left(\mathrm{R}^{2}\right)$. If all observations lie on the regression line, $R^{2}=1$, if there is no linear relationship between the dependent and the independent variable, $R^{2}=0 . R^{2}$ is a measure of goodness of fit, and $R^{2}=0$ does not mean that there is no relationship between variables. That is, it indicates that there is no direct relationship between the variables.

\section{Results and Discussions}

This study, in which the species $S$. vomeracea was used as material, was conducted for two years in Bafra's ecological conditions in 2018 and 2019. Pre-planting seedling height, seedling tuber width and seedling tuber 
250

length and post-harvest plant height, tuber width, tuber length, tuber fresh weight, tuber dry weight, number of leaves, leaf width, leaf length, total leaf area, means of leaf area characteristics were examined in seedlings collected and divided into seven different groups according to the size of their biomass. The statistical analyzes performed using the data obtained are presented as items.

\section{Comparison of morphological characteristics of seedling groups}

Seedlings in the research were divided into seven groups according to their morphological characteristics. In these groups, variance analysis was performed according to seedling height, seedling tuber width, and seedling tuber length properties and the results were analyzed according to Duncan's multiple comparison test (Table 2). Within seedling groups, the best results according to all characteristics were obtained from seedling group number seven. In addition, it was found that there was a significant difference between the groups depending on the years. This indicates an increase in seedling height, seedling tuber width, and seedling tuber length depending on years.

Table 2. Means and significance of investigated parameters of $S$. vomerecea in planting date

\begin{tabular}{|c|c|c|c|c|c|c|}
\hline \multirow{2}{*}{$\begin{array}{c}\text { Seedling groups } \\
1\end{array}$} & \multicolumn{2}{|c|}{$\begin{array}{l}\text { Seedling height } \\
(\mathrm{cm})\end{array}$} & \multicolumn{2}{|c|}{$\begin{array}{l}\text { Seedling's tuber width } \\
(\mathrm{mm})\end{array}$} & \multicolumn{2}{|c|}{$\begin{array}{l}\text { Seedling's tuber length } \\
(\mathrm{mm})\end{array}$} \\
\hline & 5.39 & $\mathrm{e}$ & 3.93 & $\mathrm{e}$ & 6.35 & $\mathrm{c}$ \\
\hline 2 & 7.77 & $\mathrm{~d}$ & 5.65 & $\mathrm{~d}$ & 8.61 & bc \\
\hline 3 & 8.51 & $\mathrm{~d}$ & 6.39 & $\mathrm{~d}$ & 8.38 & $\mathrm{c}$ \\
\hline 4 & 13.43 & $\mathrm{c}$ & 8.23 & $\mathrm{c}$ & 10.83 & $\mathrm{~b}$ \\
\hline 5 & 16.72 & $\mathrm{~b}$ & 9.30 & $\mathrm{c}$ & 13.19 & $\mathrm{a}$ \\
\hline 6 & 18.33 & $\mathrm{a}$ & 11.69 & $\mathrm{~b}$ & 15.05 & $\mathrm{a}$ \\
\hline 7 & 19.31 & $\mathrm{a}$ & 13.98 & $\mathrm{a}$ & 14.63 & $\mathrm{a}$ \\
\hline Mean & 12.78 & & 8.45 & & 11.00 & \\
\hline \multicolumn{7}{|c|}{ Mean Square ve Significance } \\
\hline Year $(Y)$ & 698.25 & $* *$ & 750.32 & "* & 1324.75 & "* \\
\hline Grup (G) & 187.29 & $* *$ & 74.31 & * & 68.62 & "* \\
\hline $\mathrm{Y} \times \mathrm{G}$ & 62.46 & "* & 9.56 & $" *$ & 6.99 & \\
\hline Error & 0.90 & & 1.29 & & 3.87 & \\
\hline
\end{tabular}

${ }^{*} ; \mathrm{p}<0.05,{ }^{* *} ; \mathrm{p}<0.01$. Values followed by different letters in each column are significantly different $(\mathrm{p}<0.01)$ according to Duncan Test

In addition, plant height, tuber width, tuber length, tuber fresh weight, tuber dry weight, number of leaves (per/plant), leaf width $(\mathrm{mm})$, leaf length $(\mathrm{mm})$, total leaf area $\left(\mathrm{mm}^{2}\right)$, means of leaf area $\left(\mathrm{mm}^{2}\right)$ characteristics were examined according to seedling groups (Table 3). According to these results, when all characteristics are taken into account, the best results are obtained from group seven. Depending on the years, there are very significant differences between all characteristics, except leaf parameters (number of leaves, leaf width, leaf length, total leaf area, means of leaf area). The increase in the size of the tuber over the years positively affects other properties as well.

In this study, descriptive statistics of two-year average data (Tables 2,3) are given in Table 4, in which vegetative characteristics of $S$. vomeracea species are discussed. $S$. vomeracea species, is one of the salep orchid species collected the most from nature, together with Orchis santa and Orchis italica Poiret (Tutar et al., 2012). Studies have focused on the propagation in in vitro conditions, especially in embryo culture, due to the low number of tubers and the germination barriers of seeds. Since these studies are usually completed after obtaining the plant, there are not many studies reporting the botanical and tuber characteristics of the species. 
Table 3. Means and significance of investigated parameters of $S$. vomerecea in harvest date

\begin{tabular}{|c|c|c|c|c|c|c|c|c|c|c|c|c|c|c|c|c|c|c|c|c|}
\hline \multirow{2}{*}{$\begin{array}{c}\begin{array}{c}\text { Seedling } \\
\text { groups }\end{array} \\
1\end{array}$} & \multicolumn{2}{|l|}{ PH } & \multicolumn{2}{|c|}{$T W$} & \multicolumn{2}{|l|}{ TL } & \multicolumn{2}{|c|}{ TFW } & \multicolumn{2}{|c|}{ TDW } & \multicolumn{2}{|c|}{ NL } & \multicolumn{2}{|c|}{$\mathbf{L W}$} & \multicolumn{2}{|l|}{ LL } & \multicolumn{2}{|l|}{ TLA } & \multicolumn{2}{|l|}{ MLA } \\
\hline & 6.79 & e & 11.96 & $\mathrm{e}$ & 17.76 & $\mathrm{e}$ & 2.07 & $\mathrm{c}$ & 0.45 & $\mathrm{c}$ & 3.00 & $f$ & 3.78 & $\mathrm{~d}$ & 45.82 & $\mathrm{~d}$ & 389.83 & $\mathrm{e}$ & 129.54 & $\mathrm{f}$ \\
\hline 2 & 9.84 & d & 16.15 & $\mathrm{~d}$ & 24.55 & $\mathrm{~cd}$ & 4.02 & $\mathrm{c}$ & 0.95 & $\mathrm{bc}$ & 4.33 & $\mathrm{e}$ & 4.25 & d & 51.46 & $\mathrm{~d}$ & 803.41 & de & 192.81 & $\mathrm{f}$ \\
\hline 3 & 10.95 & $\mathrm{~d}$ & 17.34 & $\mathrm{~d}$ & 22.51 & de & 4.20 & $\mathrm{c}$ & 0.75 & $c$ & 5.33 & $\mathrm{~d}$ & 6.60 & $\mathrm{c}$ & 60.37 & c & 1656.09 & d & 306.21 & \\
\hline 4 & 20.01 & $\mathrm{c}$ & 21.67 & $\mathrm{c}$ & 28.99 & $\mathrm{bc}$ & 6.92 & $\mathrm{~b}$ & 1.43 & $\mathrm{~b}$ & 6.17 & $\mathrm{c}$ & 9.64 & $\mathrm{~b}$ & 71.31 & $\mathrm{~b}$ & 3258.18 & $\mathrm{c}$ & 523.11 & d \\
\hline 5 & 29.85 & $\mathrm{~b}$ & 23.40 & bc & 32.44 & $\mathrm{ab}$ & 8.05 & $\mathrm{ab}$ & 1.50 & $\mathrm{~b}$ & 8.00 & $\mathrm{~b}$ & 10.74 & $\mathrm{~b}$ & 76.73 & $\mathrm{~b}$ & 5029.41 & b & 628.42 & c \\
\hline 6 & 30.40 & $\mathrm{~b}$ & 26.15 & $\mathrm{~b}$ & 35.54 & $\mathrm{a}$ & 10.17 & $\mathrm{a}$ & 1.45 & $\mathrm{~b}$ & 7.67 & $\mathrm{~b}$ & 13.24 & $\mathrm{a}$ & 95.33 & $\mathrm{a}$ & 6898.01 & $\mathrm{a}$ & 899.17 & $\mathrm{a}$ \\
\hline 7 & 33.21 & $\mathrm{a}$ & 30.56 & $\mathrm{a}$ & 31.73 & $\mathrm{ab}$ & 10.21 & $\mathrm{a}$ & 2.46 & $\mathrm{a}$ & 9.83 & $\mathrm{a}$ & 13.52 & $\mathrm{a}$ & 86.93 & $\mathrm{a}$ & 7452.17 & $\mathrm{a}$ & 756.55 & b \\
\hline Mean & 20.15 & & 21.03 & & 27.65 & & 6.52 & & 1.28 & & 6.33 & & 8.82 & & 69.71 & & 3641.01 & & 490.83 & \\
\hline \multicolumn{21}{|c|}{ Mean Square vs Significance } \\
\hline Year $(\mathbf{Y})$ & 452.25 & “ & 2930.8 & $"$ & 5105.5 & "* & 914.67 & “ & 35.38 & & 1.52 & & 0.12 & & 7.66 & & 14969.57 & & 891.57 & \\
\hline Grup $(G)$ & 739.16 & “ & 242.78 & " & 237.48 & " & 60.91 & " & 2.57 & “” & 32.94 & 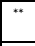 & 97.12 & " & 1995 & $"$ & 49769303 & " & 510754 & \\
\hline $\mathbf{Y} \times \mathbf{G}$ & 40.56 & & 16.32 & & 25.56 & & 20.73 & " & 0.77 & & 2.80 & " & 0.00 & & 0.08 & & 767575.7 & & 44.95 & \\
\hline Error & 4.07 & & 8.18 & & 25.86 & & 4.43 & & 0.26 & & 0.41 & & 1.55 & & 54.72 & & 682503.4 & & 7264.16 & \\
\hline
\end{tabular}

Table 4. Descriptive statistics for investigated parameters of $S$. vomerecea

\begin{tabular}{|c|c|c|c|}
\hline \multicolumn{2}{|c|}{ Set of variables I. (Planting parameters) } & \multicolumn{2}{|c|}{ Set of variables II. (Harvest parameters) } \\
\hline Variables & $\overline{\mathrm{X}} \pm \boldsymbol{S}_{\bar{x}}$ & Variables & $\overline{\mathbf{X}} \pm S_{\bar{x}}$ \\
\hline Seedling height $(\mathrm{cm})$ & $12.778 \pm 1.136$ & Plant height $(\mathrm{cm})$ & $20.150 \pm 1.745$ \\
\hline Seedling's tuber width $(\mathrm{mm})$ & $8.451 \pm 0.865$ & Tuber width $(\mathrm{mm})$ & $21.031 \pm 1.655$ \\
\hline \multirow[t]{8}{*}{ Seedling's tuber length $(\mathrm{mm})$} & $11.005 \pm 1.047$ & Tuber length $(\mathrm{mm})$ & $27.646 \pm 2.074$ \\
\hline & & Tuber fresh weight $(\mathrm{g})$ & $6.520 \pm 0.942$ \\
\hline & & Tuber dry weight $(\mathrm{g})$ & $1.282 \pm 0.191$ \\
\hline & & Number of leaves (per/plant) & $6.333 \pm 0.363$ \\
\hline & & Leaf width $(\mathrm{mm})$ & $8.824 \pm 0.603$ \\
\hline & & Leaf length $(\mathrm{mm})$ & $69.707 \pm 2.802$ \\
\hline & & Total leaf area $\left(\mathrm{mm}^{2}\right)$ & $3641.013 \pm 432.658$ \\
\hline & & Mean leaf area $\left(\mathrm{mm}^{2}\right)$ & $490.830 \pm 43.571$ \\
\hline
\end{tabular}

$\overline{\mathrm{X}}$ : Means of investigated parameters, $S_{\bar{x}}:$ Standard error

There were some studies examining some botanical characteristics of Serapias bergonii (Syn: S. vomeracea subsp. laxiflora (Soo) Golz et Reinhard) (Delforge, 2006; Venhuis et al., 2007) species (Sevgi et al., 2012) and S. vomeracea species (Renz and Taubenheim, 1984; Guler, 2005; Delforge, 2006; Sandal, 2009; Arabaci et al., 2014; Ertas et al., 2019) in the $S$. vomeracea group (Ertas et al., 2019). In the aforementioned studies, plant height values were reported by Renz and Taubenheim (1984) as 10-40 cm, by Delforge (2006) as $15-42 \mathrm{~cm}$, by Guler (2005) as $10-46 \mathrm{~cm}$, by Sandal (2009) as $10-30 \mathrm{~cm}$, by Sevgi et al. (2012) as $226.88 \pm 3.63 \mathrm{~mm}$, by Arabaci et al. (2014) as $15.62-31.33 \mathrm{~cm}$ and by Ertas et al. (2019) as $24.33 \pm 5.70 \mathrm{~cm}$. In the studies, plant height values ranged between $6.79-33.21 \mathrm{~cm}$ and the average was determined as $20.150 \pm 1.745 \mathrm{~cm}$. Sevgi et al. (2012) reported that the average tuber width and length values of this species were $11.28 \pm 0.23 \mathrm{~mm}$ (between $5-19$ $\mathrm{mm}$ ) and $16.41 \pm 0.35 \mathrm{~mm}$ (between $8-30 \mathrm{~mm}$ ), respectively. Arabaci et al. (2014) reported that the diameter of the tuber varied between $13.93-17.10 \mathrm{~mm}$. In our study, these characteristics were measured as $21.03 \pm 1.65$ $\mathrm{mm}$ and $27.65 \pm 2.07 \mathrm{~mm}$, respectively, which is higher than the measurements of Sevgi et al. (2012) and Arabaci et al. (2014). Sevgi et al. (2012) conducted their research on the tubers they had collected from nature. In this study, tubers which were grown in more suitable conditions for two years after being harvested from 


\section{2}

nature, are discussed. Arabaci et al. (2014) carried out studies in an ecology which has a drier climate in terms of working conditions, and acquired 2.49-5.71 g/plant fresh yield with 1.37-1.96 tubers/plants. Similarly, while Ertas et al. (2019) acquired $5.30 \pm 0.25 \mathrm{~g}$ fresh yield, meaning $4.69 \mathrm{~g} /$ tuber yield for each tuber, from a plant producing an average of $1.13 \pm 0.34$ tubers, in this study, the datas ranged between 2.07-10.21 grams, and the average tuber fresh weight was $6.52 \pm 0.94 \mathrm{~g} /$ tuber. As can be seen in Figure 2, the yield increases to 6.92-10.21 grams when the average data of plants that have not yet passed into flowering are ignored.

According to Delforge (2006) S. vomeracea species has 6-9 leaves which are 6-14 cm in length. In this study, the number of leaves ranging from 3.00-9.83, belonging to an average of $6.33 \pm 0.36$ species, were reported to be similar in different studies. Guler (2005) reported 4-9, Sandal (2009) reported 4-6 and Ertas et al. (2019) reported $3.50 \pm 0.70$ units/plant. Evaluated in 7 different groups, the leaf width of $S$. vomeracea plants varied between 3.78-13.52 mm and the leaf length ranged from 45.82 to $95.33 \mathrm{~mm}$, with an average of $8.82 \pm 0.60$ $\mathrm{mm}$ and $69.71 \pm 2.80 \mathrm{~mm}$, respectively. S. vomeracea species' leaf length and width values were reported by Guler (2005) as 4.5-17.0 cm and 0.6-2.0 cm and by Ertas et al. (2019) as $9.34 \pm 1.10 \mathrm{~cm}$ and $1.78 \pm 0.14 \mathrm{~cm}$, respectively. Compared to these studies, the leaf values obtained were within the expected range. Total leaf area was determined as $389.83-7452.17 \mathrm{~mm}^{2}$ and the average was $3641.01 \pm 432.66 \mathrm{~mm}$ and information pertaining to the leaf area of $S$. vomeracea species was reported for the first time in this study.

\section{Canonical correlation analysis}

In the second step, canonical correlation analysis was performed to examine and explain the relationship between two sets of variables (planting and harvest characteristics). For this analysis, the data of $S$. vomeracea measured in 2018-2019 were used. For this, the three parameter data in Table 1 were used, by ignoring seedling groups, and a variable set of "planting parameters" consisting of three variables was formed. For the second set of variables, the data of the ten parameters seen in Table 2 were used by ignoring seedling groups, and a variable set of "Harvest parameters" consisting of ten variables was formed. The relationship between the variable sets of "planting parameters" and "harvest parameters" of salep orchids and the contribution of each set of variables, if any, to this relationship was examined and explained by canonical correlation analysis in S. vomeracea.

Since canonical correlation analysis examines the complex relationship structure between variable sets, the difficulties in interpreting the results have put the use of this analysis technique into the background. However, in the biological studies, examining the relationship structure between the characteristics focused on by canonical correlation analysis and not by simple correlation coefficients, without disturbing the relationship structure between these characteristics, will provide more information to the researchers (Keskin et al., 2005). In recent years, studies evaluating biological data by using multivariate statistical approaches have been frequently encountered. Vainionpaa et al. (2000) applied canonical correlation analysis in order to determine the factors that make up quality and to examine the relationship between quality characteristics and production factors in a data set containing different structural and saturation characteristics of different potato cultures. In the results of their study on Karayaka hoggets, Cankaya et al. (2009) stated that explaining the relationships between morphological characteristics taken in different periods with canonical correlation analysis would provide time and financial gain by contributing to selection. Xian-Li et al. (2008) explained the relationship between vegetation, soil and topography, and Ekana and Orimoogunje (2012) explained the multivariate relationships between vegetative characteristics of plant communities and soil in forest, fallow and fields, where cocoa was grown, with canonical correlation analysis (Saglam, 2013). Soganci (2017) used canonical correlation analysis to determine the relationship between some agronomic characteristics affecting yield in 246 local dried bean genotypes collected from 8 locations.

Descriptive statistics of the parameters discussed in the study are given in Table 4. The table indicates that when a $13 \mathrm{~cm}$ tall $S$. vomeracea seedling with a diameter of $8 \times 11 \mathrm{~mm}$ tuber is planted, it can form a tuber of $21 \times 28 \mathrm{~mm}$ size at the end of the season (Table 4). Correlation coefficients of pair relationships of the investigated characteristics and their significance controls are given in Table 5 . When the table was examined, 
it was found that there was a significant relationship on $p<0.01$ level between all parameters, except $p<0.05$ significance level between number of leaves and seedling tuber length and tuber length. In the planting variable set, the strongest positive correlation was found between seedling's tuber width and seedling's tuber length $\left(0.935^{*}\right)$. In the harvest variable set, it was found that the strongest positive relationships within the set were between the characteristics of leaves. The significant strong positive correlation of seedling tuber width and seedling tuber length properties on tuber fresh yield and tuber dry yield is remarkable.

Table 5. Correlation matrix results for investigated parameters of $S$. vomerecea

\begin{tabular}{|l|l|l|l|l|l|l|l|l|l|l|l|l|l|}
\hline Variables & SH & STW & STL & PH & TW & TL & TFW & TDW & NL & LW & LL & TLA & MLA \\
\hline SH & 1 & & & & & & & & & & & & \\
\hline STW & $.917^{* *}$ & 1 & & & & & & & & & & & \\
\hline STL & $.848^{* *}$ & $.935^{* *}$ & 1 & & & & & & & & & & \\
\hline PH & $.897^{* *}$ & $.779^{* *}$ & $.706^{* *}$ & 1 & & & & & & & & & \\
\hline TW & $.889^{* *}$ & $.988^{* *}$ & $.945^{* *}$ & $.755^{* *}$ & 1 & & & & & & & & \\
\hline TL & $.826^{* *}$ & $.900^{* *}$ & $.984^{* *}$ & $.671^{* *}$ & $.920^{* *}$ & 1 & & & & & & & \\
\hline TFW & $.898^{* *}$ & $.951^{* *}$ & $.973^{* *}$ & $.744^{* *}$ & $.954^{* *}$ & $.965^{* *}$ & 1 & & & & & & \\
\hline TDW & $.849^{* *}$ & $.917^{* *}$ & $.923^{* *}$ & $.688^{* *}$ & $.918^{* *}$ & $.910^{* *}$ & $.946^{*}$ & 1 & & & & & \\
\hline NL & $.694^{* *}$ & $.523^{* *}$ & $.376^{*}$ & $.848^{* *}$ & $.487^{* *}$ & $.336^{*}$ & $.450^{* *}$ & $.441^{* *}$ & 1 & & & & \\
\hline LW & $.680^{* *}$ & $.567^{* *}$ & $.468^{* *}$ & $.858^{* *}$ & $.549^{* *}$ & $.433^{* *}$ & $.501^{* *}$ & $.462^{* *}$ & $.863^{* *}$ & 1 & & & \\
\hline LL & $.673^{* *}$ & $.547^{* *}$ & $.475^{* *}$ & $.835^{* *}$ & $.525^{* *}$ & $.453^{* *}$ & $.500^{* *}$ & $.437^{* *}$ & $.812^{* *}$ & $.927^{* *}$ & 1 & & \\
\hline TLA & $.714^{* *}$ & $.577^{* *}$ & $.478^{* *}$ & $.890^{* *}$ & $.540^{* *}$ & $.438^{* *}$ & $.519^{* *}$ & $.489^{* *}$ & $.920^{* *}$ & $.945^{* *}$ & $.931^{* *}$ & 1 & \\
\hline MLA & $.664^{* *}$ & $.522^{* *}$ & $.457^{* *}$ & $.851^{* *}$ & $.499^{* *}$ & $.439^{* *}$ & $.484^{* *}$ & $.421^{* *}$ & $.830^{* *}$ & $.965^{* *}$ & $.973^{* *}$ & $.958^{* *}$ & 1 \\
\hline
\end{tabular}

${ }^{*}$; p $<0.05,{ }^{* *} ; \mathrm{p}<0.01$, SH; Seedling height (cm), STW; Seedling's tuber width (mm), STL; Seedling's tuber length (mm), PH; Plant height (cm), TW; Tuber width (mm), TL; Tuber length (mm), TFW; Tuber fresh weight (g), TDW; Tuber dry weight (g), NL; Number of leaves (per/plant), LW; Leaf width (mm), LL; Leaf length (mm), TLA; Total leaf area $\left(\mathrm{mm}^{2}\right)$, MLA; Mean leaf area $\left(\mathrm{mm}^{2}\right)$.

In the study, 3 pairs of canonical variables are obtained when there are 3 variables in the planting characteristics variable set and when there are 10 variables in the harvest characteristics variable set.

When performing canonical correlation analysis, it is first checked whether the established canonical model is significant. Table 6 shows the results of Pillai's criterion, Hotelling's trace, Wilk's lambda and Roy's GCR tests. In general, Wilk's $\lambda$ is preferred by researchers as the most useful one (Sherry and Henson, 2005). According to these results, the canonical model created is statistically significant [Wilk's $\lambda=0.0004, F(30$, $85.00)=36.534, \mathrm{p}<0.001]$. Therefore, it can be said that there is a significant relationship between "planting characteristics" and "harvest characteristics" variable sets. Wilk's $\lambda$ test statistic is used for testing the null hypothesis that the given canonical correlation and all smaller ones are equal to zero in the population (Heenkenda and Chandrakumara, 2015). Some researchers interpret the effect size of the relationship with the inverse value of Wilk's $\lambda$ (Temurtas, 2016). Therefore, it can be calculated as 1 - Wilk's $\lambda=1-0.0004=0.9996$ $[(1-0.991) \times(1-0.827) \times(1-0.712)=0.0004]$. Accordingly, the shared variance between the two sets of variables is $99.96 \%$.

Table 6. Multivariate tests of significance $(S=3, M=3, N=131 / 2)$

\begin{tabular}{|l|l|l|l|l|l|}
\hline Test Name & Value & Approximate F & Hypothesis DF & Error DF & Significance of F \\
\hline Pillais's & 2.530 & 16.705 & 30.00 & 93.00 & 0.00 \\
\hline Hotellings's & 115.860 & 106.849 & 30.00 & 83.00 & 0.00 \\
\hline Wilks's & 0.0004 & 36.534 & 30.00 & 85.00 & 0.00 \\
\hline Roys's & 0.991 & & & & \\
\hline
\end{tabular}

DF - Degree of freedom 
While the established canonical model is meaningful, it needs to be tested in each canonical function. In Table 7, eigenvalues and canonical correlations are given for the three canonical functions developed for the model. When the table is examined, it is seen that the canonical correlation of the first canonical function is 0.995, and this function explains $99.1 \%$ of the variance between two sets of variables. The contribution of the second and third canonical functions is $82.7 \%$ and $71.2 \%$, respectively, and it is seen that it contributes to the explanation of the variance between two sets of variables in all three functions, the highest being the first function.

Table 7. Eigenvalues and canonical correlations

\begin{tabular}{|c|c|c|c|c|c|}
\hline Root & Eigenvalue & $\begin{array}{c}\text { Percent } \\
(\%)\end{array}$ & $\begin{array}{c}\text { Cumulative percent } \\
(\%)\end{array}$ & $\begin{array}{c}\text { Canonical } \\
\text { correlation }\end{array}$ & $\begin{array}{c}\text { Squared } \\
\text { correlations }\end{array}$ \\
\hline 1 & 108.596 & 93.730 & 93.730 & 0.995 & 0.991 \\
\hline 2 & 4.788 & 4.133 & 97.863 & 0.910 & 0.827 \\
\hline 3 & 2.476 & 2.137 & 100.00 & 0.844 & 0.712 \\
\hline
\end{tabular}

The results of the dimension reduction analysis used to evaluate the canonical functions are given in Table 8. Accordingly, there is a significant relationship between the variable sets of "planting parameters" and "harvest parameters" for all three functions ["Wilk's $\lambda=0.0005, \mathrm{~F}(30,85.80)=36.5339$ " and "Wilk's $\lambda=$ $0.0497, \mathrm{~F}(18,60.00)=11.6184$ " and “Wilk's $\lambda=0.2877, \mathrm{~F}(8,31.00)=9.5940$ ”, $\mathrm{p}<0.001$, respectively].

Table 8. Dimension reduction analysis

\begin{tabular}{|c|c|c|c|c|c|}
\hline Roots & Wilks $\lambda$ & F & Hypothesis DF & Error DF & Significance of F \\
\hline 1 TO 3 & 0.0005 & 36.5339 & 30.00 & 85.80 & 0.00 \\
\hline 2 TO 3 & 0.0497 & 11.6184 & 18.00 & 60.00 & 0.00 \\
\hline 3 TO 3 & 0.2877 & 9.5940 & 8.00 & 31.00 & 0.00 \\
\hline
\end{tabular}

In Table 9, standardized canonical coefficients, structure coefficients, squares of structure coefficients, and communality coefficients are given for two canonical functions. Statistically, all 3 functions are significant. Here, the coefficients of the first two canonical functions are given in order to make comparisons. Standardized canonical coefficients (SC) give the contribution of each of the variables to canonical functions. Accordingly, the contributions of "planting characteristics" variables to the first canonical function are SH (-0.0382), STW $(-0.0440)$ and STL (-0.5413), and the contribution of "harvest characteristics" variables to the canonical functions can be followed in Table 9. Canonical coefficients are the determinant coefficients used to estimate the values of the characteristics examined at the time of harvest, by using the morphological characteristics taken during planting. However, it is not appropriate to use these coefficients in case of multiple connections between the examined characteristics. Therefore, instead of these coefficients, it is necessary to use canonical loads that show the relationship between canonical variables and original variables (Akbas and Takma, 2005). That is, since the interpretation of standardized canonical correlations is not healthy, especially if there is multiple linear connection, it is a more accurate approach to interpret the structure coefficients given as correlations between canonical variables and both sets of variables (Temurtas, 2016).

When Table 9 is examined, it is seen that all variables have great contributions for the first canonical function. In terms of structure coefficients $(\mathrm{Rc})$ signs, the evaluation is that those with the same signs are together, while those with different signs are in the opposite relationship. Since all variables in the first canonical function have structure coefficient with the same signs, as seedling size and planted tuber sizes grow, the yield and other characteristics that will occur at the time of harvest will also be increased. In the second function in which a similar structure is generally seen, seedling length and tuber width will be interpreted as contributing to yield and other characteristics at the time of harvest rather than planted tuber length. What is 
particularly interesting in the second function is the positive correlation between the length of the planted, the length of the tuber harvested and its fresh and dry yields.

Table 9. Canonical association of planting and harvest parameters of $S$. vomerecea

\begin{tabular}{|c|c|c|c|c|c|c|c|}
\hline \multirow{2}{*}{ Variables } & \multicolumn{3}{|c|}{ Canonical function 1} & \multicolumn{3}{|c|}{ Canonical function 2} & \multirow[b]{2}{*}{$h^{2}$} \\
\hline & SC & Rc & $\mathrm{Rc}^{2}$ & $\mathrm{SC}$ & $\mathrm{Rc}$ & $\mathrm{Rc}^{2}$ & \\
\hline $\mathrm{SH}$ & -0.0382 & -0.9009 & 81.1531 & -0.8861 & 0.0505 & 0.2545 & 81.41 \\
\hline STW & -0.0440 & -0.9814 & 96.3107 & 3.4654 & 0.1844 & 3.4000 & 99.71 \\
\hline STL & -0.5413 & -0.9854 & 97.0915 & -2.6414 & -0.1536 & 2.3590 & 99.45 \\
\hline $\mathrm{PH}$ & -0.1057 & -0.7631 & 58.2322 & -0.5626 & 0.0418 & 0.1745 & 58.41 \\
\hline TW & -0.4631 & -0.9854 & 97.0934 & 2.9399 & 0.1549 & 2.3985 & 99.49 \\
\hline $\mathrm{TL}$ & -0.3145 & -0.9648 & 93.0878 & -2.6258 & -0.2339 & 5.4690 & 98.56 \\
\hline TFW & -0.1768 & -0.9842 & 96.8669 & -0.1289 & -0.0785 & 0.6165 & 97.48 \\
\hline TDW & 0.0173 & -0.9403 & 88.4239 & 0.1348 & -0.0136 & 0.0186 & 88.44 \\
\hline NL & 0.1521 & -0.4624 & 21.3842 & 0.0699 & 0.2232 & 4.9796 & 26.36 \\
\hline LW & -0.0701 & -0.5309 & 28.1844 & -0.5666 & 0.1383 & 1.9132 & 30.10 \\
\hline LL & -0.0940 & -0.5261 & 27.6813 & -0.2802 & 0.0505 & 0.2552 & 27.94 \\
\hline TLA & -0.3158 & -0.5423 & 29.4089 & 0.0757 & 0.1155 & 1.3331 & 30.74 \\
\hline MLA & 0.3681 & -0.5047 & 25.4762 & 0.8735 & 0.0161 & 0.0258 & 25.50 \\
\hline
\end{tabular}

Structure coefficients $(\mathrm{Rc})$ greater than $|.45|$ are underlined. Communality coefficients $\left(\mathrm{h}^{2}\right)$ greater than $45 \%$ are underlined. SC; Standardized canonical function coefficient, Rc; Structure coefficients (canonical loading), Rc ${ }^{2}$; Squared structure coefficient (\%), $\mathrm{h}^{2}$; Communality coefficients (\%).

The number of leaves and leaf sizes have positive relationship with the length of the seedling planted. Although the $\mathrm{h}^{2}$ values of the leaf characteristics in the variable set of "harvest parameters" are smaller than $45 \%$, they contribute less to the variance between the two sets of variables than the other parameters. According to these results, the most important positive contribution to the harvest characteristics is made by the tuber sizes planted, especially the seedling tuber length $\left(\mathrm{h}^{2} ; 99.71\right)$. The data obtained from the tubers (TW; 99.49\%, TL; 98.56\%, TFW; 97.48\%, TDW; 88.44\%) made the greatest contribution to the explanatory power of the canonical variables.

\section{Leaf area modeling}

Leaf area prediction models aim to estimate leaf area non-destructively and these models are important parameter in explaining some physiological events such as light intensity, photosynthesis, respiration, plant water consumption (Uzun, 1996; Centritto et al., 2000; Yerkin and Temizel, 2018). Furthermore, these models enable researchers to carry out leaf area measurements on the same plants resulting in reduced experimental variability (Oner et al., 2011).

Before creating the model, variance analysis was performed to determine the relationship between the parameters. As a result of the analysis, it was found that there was a significant relationship between the characteristics that made up the model (Table 10).

Table 10. Analysis of variance for leaf areas of $S$. vomerecea

\begin{tabular}{|c|c|c|c|c|c|}
\hline Source & DF & Sum of squares & Mean squares & F & $\operatorname{Pr}>\mathrm{F}$ \\
\hline Model & 2 & 11044935.116 & 5522467.558 & 743.959 & $<\mathbf{0 . 0 0 0 1}$ \\
\hline Error & 133 & 987270.234 & 7423.084 & & \\
\hline Corrected Total & 135 & 12032205.350 & & & \\
\hline
\end{tabular}

Computed against model $\mathrm{Y}=\mathrm{Mean}(\mathrm{Y})$. DF; Degree of freedom 
Leaf width and length as independent variable, leaf area as dependent variable were selected as the model parameters. As a result of the analysis made according to these two independent variables, leaf area model was formed as follows (Table 11).

$$
L A\left(m^{2}\right)=-371.7228+34.3134 \times L W+8.1783 \times L L
$$

Table 11. Model parameters (Leaf area, $\mathrm{mm}^{2}$ )

\begin{tabular}{|c|c|c|c|c|c|c|}
\hline Source & Value & Standard error & $\mathrm{t}$ & $\operatorname{Pr}>|\mathrm{t}|$ & Lower bound (95\%) & Upper bound (95\%) \\
\hline Intercept & -371.723 & 26.711 & -13.916 & $<0.0001$ & -424.556 & -318.890 \\
\hline Leaf width $(\mathrm{mm})$ & 34.313 & 2.546 & 13.475 & $<0.0001$ & 29.277 & 39.350 \\
\hline Leaf length $(\mathrm{mm})$ & 8.178 & 0.483 & 16.917 & $<0.0001$ & 7.222 & 9.135 \\
\hline
\end{tabular}

When the leaf area values obtained with this model were compared graphically with the actual leaf area values, similarity of $91.89 \%$ was calculated (Figure 3 ). This value shows that the obtained mathematical model gives highly accurate results.

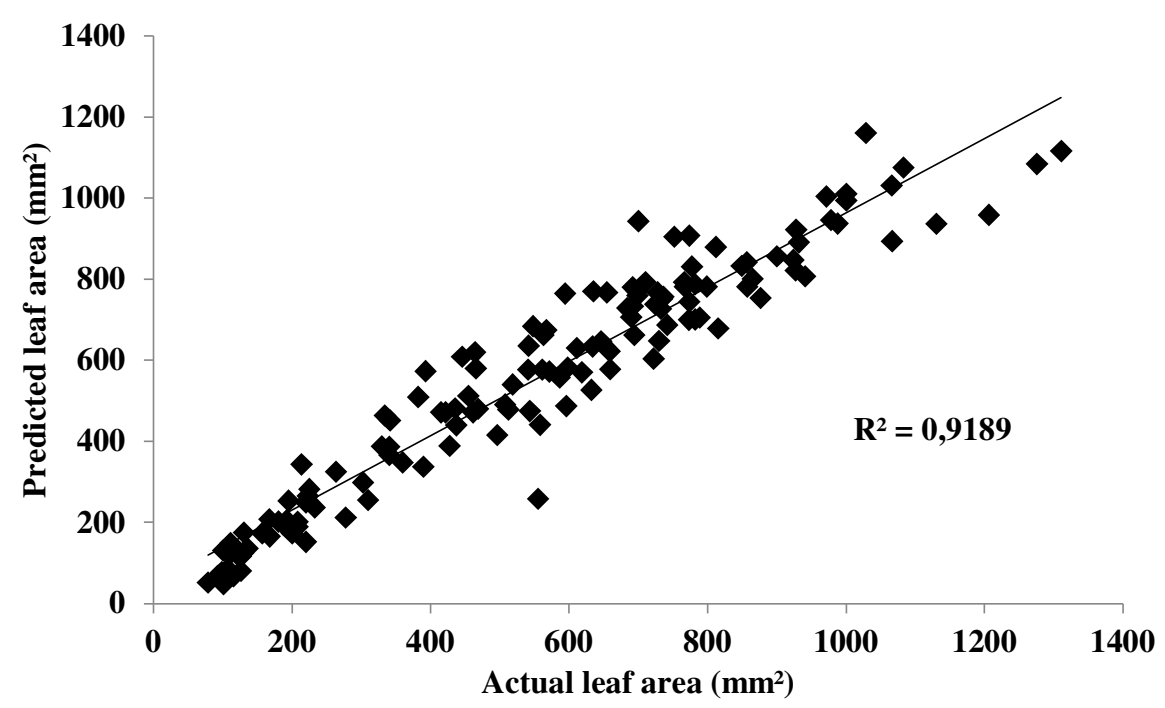

Figure 3. The relationship between actual leaf area $\left(\mathrm{mm}^{2}\right)$ and predicted leaf area $\left(\mathrm{mm}^{2}\right)$

\section{Conclusions}

S. vomeracea salep orchid is the most common tuberous orchid seen in temperate regions. Although it is common in natural flora, it is one of the species that cannot be produced because of its microscopic seeds which are embryo-free. The tubers are used as seeds in annual salep orchids. However, the planted tuber (main tuber), produces one young tuber and thus survives another generation. No data are available on developmental biology and growth performances due to generative and vegetative production constraints. The studies serve as assessments. In this study which was carried out in order to make up for this deficiency and was repeated for two years, seed tubers of different sizes and seedlings developed from them were used. According to the canonical correlation results, the agronomic characteristics to be seen in the harvesting stage depend on the size of the main tuber, especially the tuber length. In other words, when the size of the seed tuber is known, the morphological characteristics of the future plant can be estimated. Leaf area estimation modelling based on the leaf properties provided high accuracy results. This will make important contributions to the reduction of experimental variability in future studies on the species. 


\section{Acknowledgements}

This study was supported by Ondokuz Mayis University with project named "Investigation of Sustainable Agriculture Opportunities in Serapias Species Salep Orchids (PYO.BMY.1901.18.001)”.

\section{Conflict of Interests}

The authors declare that there are no conflicts of interest related to this article.

\section{References}

Acemi A, Cobanoglu O, Turker-Kaya S (2019). FTIR-based comparative analysis of glucomannan contents in some tuberous orchids, and effects of pre-processing on glucomannan measurement. Journal of Science of Food and Agriculture 99(7):3681-3686. https://doi.org/10.1002/jsfa.9596

Acemi A, Ozen F (2019). Optimization of in vitro asymbiotic seed germination protocol for Serapias vomeracea. The EuroBiotech Journal 3(3):143-151. https://doi.org/10.2478/ebtj-2019-0017

Akbas Y, Takma C (2005). Canonical correlation analysis for studying the relationship between egg production traits and body weight, egg weight and age at sexual maturity in layers. Czech Journal of Animal Science 50(4):163-168. https://doi.org/10.17221/4010-CJAS

Albayrak AS (2006). Applied Multivariate Statistical Techniques. Asil Publications, Ankara.

Arabaci O, Tutar M, Ogretmen NG, Yasar F, Tan U (2014). Effects of different cultural practices in salep orchids. In: Turkey II. Medicinal and aromatic plants symposium proceeding books, 23-25 September, Yalova, pp 479-487.

Attri LA (2016). Terapeutic potential of orchids. World Journal of Pharmacy and Pharmaceutical Science 5(2):438-446.

Bektas E, Cuce M, Sokmen A (2013). In vitro germination, protocorm formation, and plantlet development of Orchis coriophora (Orchidaceae), a naturally growing orchid species in Turkey. Turkish Journal of Botany 37(2):336-342. https://doi.org/10.3906/bot-1205-28

Belusci F, Pellegrino G, Palermo AM, Musacchio A (2008). Phylogenetic relationships in the orchid genus Serapias L. based on noncodingregions of the chloroplast genome. Molecular Phylogenetics and Evolution 47(3):986-991. https://doi.org/10.1016/j.ympev.2008.03.019

Bilgin OC, Emsen E, Davis ME (2003). An application of canonical correlation analysis to relationships between the head and scrotum measurements in awassi fat tailed Lambs. Journal of Animal and Veterinary Advances 2:343-349. http://medwelljournals.com/abstract/?doi=javaa.2003.343.349

Brullo C, Emerico SD, Pulvirenti S (2014). A cytological study of four Sicilian Serapias (Orchidaceae). Caryologia 67(3):260264. https://doi.org/10.1080/0144235X.2014.974354

Bulpitt CJ (2005). The uses and misuses of orchids in medicine. QJM: An International Journal of Medicine 98(9): 625-631. https://doi.org/10.1093/qjmed/hci094

Caliskan O, Kurt D (2019a). Salep orchids from past to present with historical recordings. Turkish Journal of Agricultural Research 6(3):349-355. https://doi.org/10.19159/tutad.543576

Caliskan O, Kurt D (2019b). Description of development period of Dactylorhiza romana (Sebast.) Soo. during four consecutive years. Anadolu Journal of Agricultural Science 34(2):195-200. https://doi.org/10.7161/omuanajas.491130

Caliskan O, Kurt D, Cirak C (2019). Development of new sustainable sahlep production methods using Ophrys sphegodes subsp. mammosa (Desf.) Soo ex E. Nelson. Journal of Agricultural Science and Technology 21(6):1547-1555. http://journals.modares.ac.ir/article-23-19310-en.html

Cankaya S, Altop A, Olfaz M, Erener G (2009). Canonical correlation analysis for estimation for relationships between some traits measured at pre- and post- slaughtering periods in Karayaka hoggets. Anadolu Journal of Agricultural Science 24(1):61-66. https://doi.org/10.7161/anajas.2009.24.1.61-66 
Centritto M, Loreto F, Massacci A, Pietrini F, Villani MC, Zacchine M (2000). Improved growth and water use efficiency of cherry saplings under reduced light intensity. Ecological Research 15(4):385-392. https://doi.org/10.1046/j.14401703.2000.00359.x

Cig A, Durak ED, Isler S (2018). In vitro symbiotic germination potentials of some Anacamptis, Dactylorhiza, Orchis and Ophrys terrestrial orchid species. Applied Ecology and Environmental Research 16(4):5141-5155. https://doi.org/10.15666/aeer/1604_51415155

Delforge P (2006). Orchids of Europe, North Africa and the Middle East. Timber Press, Portland.

Ekanade O, Orimoogunje OOI (2012). Application of canonical correlation for soil-vegetation interrelationship in the cocoa belt of South Western Nigeria. Resources and Environment 2(3):87-92. https://doi.org/10.5923/j.re.20120203.02

Ertas S, Ozel A, Erden K (2019). Determination of the botanical properties and glucomannan contents of some salep species cultivated in Şanliurfa conditions. Harran Journal of Agriculture and Food Science 23(1):39-46. https://doi.org/10.29050/harranziraat.406221

Faraji Z, Nikzad H, Parivar K, Nikzad M (2013). The effect of aqueous extract of salep tubers on the structure of testis and sexual hormones in male mice. Journal of Jahrom University of Medical Sciences 11(1):61-66. https://doi.org/10.29252/jmj.11.1.10

Gorbani A, Gravendeel B, Zarre S, Boer H (2014). Illegal wild collection and international trade of CITES listed terrestrial orchid tubers in Iran. Traffic Bulletin 26(2):53-58.

Guler N (2005). Morphological and chorological studies on the orchids growing in Kazdağları. PhD Dissertation, Trakya University, Graduate School of Sciences, Tekirdag.

Gunderson BK, Muirhead RJ (1997). On estimating the dimensionality in canonical correlation analysis. Journal of Multivariate Analysis 62(1):121-136. https://doi.org/10.1006/jmva.1997.1677

Heenkenda S, Chandrakumara DPS (2015). A canonical analysis on the relationship between financial risk tolerance and household education investment in Sri Lanka. International Journal of Innovation and Economic Development 1(4):723.

Hossain MM (2011). Therapeutic orchids: traditional uses and recent advances-an overview. Fitoterapia 82:102-140. https://doi.org/10.1016/j.fitote.2010.09.007

Jagdale SP, Shimpi S, Chachad D (2009). Pharmacological studies of 'Salep'. Journal of Herbal Medicine and Toxicology 3(1):153-156.

Jalal JS, Kumar P, Pangtey YPS (2008). Ethnomedicinal orchids of Uttarakhand, Western Himalaya. Ethnobotanicl Leaflets 12(1):1227-1230.

Johnson RA, Wicherm DW (2002). Applied Multivariate Statistical Analysis (5th ed.) Prentice Hill, New Jersey.

Kasparek M, Grimm U (1999). European trade in Turkish salep with special reference to Germany. Economic Botany 53(4):396-406.

Keskin S, Kor A, Baspinar E (2005). The investigation of relationships between some traits measured pre-slaughtering and postslaughtering by using of canonical correlation analysis in Akkeçi Kids. Tarim Bilim Derg 11(2):154-159.

Kreutz CAJ (2002). The orchids of Turkey; Sahlep, Ice cream and Massacre. Green Atlas 5:98-109.

Kreutz CAJ (2009). The orchids of Turkey: botanical features, ecological requests, natural distribution areas, life threats, protection measures. Edt Alper Hüseyin Çolak, Rota Publications, Istanbul.

Molnar AV, Nagy T, Loki V, Suveges K, Takacs A, ... Tokolyi J (2017). Turkish graveyards as refuges for orchids against tuber harvest. Ecology and Evolution 7(24): 11257-11264. https://doi.org/10.1002/ece3.3562

Odabas MS, Camas N, Cirak C, Radusiene J, Valdamiras J, Ivanauskas L (2010). The quantitative effects of temperature and light intensity on phenolics accumulation in St. John's Wort (Hypericum perforatum L.). Natural Product Communications 5(4):535-540. https://doi.org/10.1177\%2F1934578X1000500408

Odabas MS, Leelaruban N, Simsek H, Padmanabhan G (2014). Quantifying impact of droughts on barley yield in North Dakota, USA using multiple linear regression and artificial neural network. Neural Network World 24(4):343-355.

Oner F, Odabas MS, Sezer I, Odabas F (2011). Leaf area prediction for corn (Zea mays L.) cultivars with multiregression analysis. Photosynthetica 49(4):637-640. https://doi.org/10.1007/s11099-011-0069-0

Ong JWL (2016). In Bed with Viruses: The Partnership Between Orchids, Fungi and Viruses. For the degree of Doctor of Philosophy. Murdoch University, Murdoch.

Ozcomak MS, Gunduz M, Demirci A, Yakut E (2012). Investigation of relationship between various climate and product data by canonical correlation analysis and data envelopment analysis methods. Journal of Economics and Administrative Sciences 26(1):111-131. https://dergipark.org.tr/tr/pub/atauniiibd/issue/2704/35696 
Pant B (2013). Medicinal orchids and their uses: Tissue culture a potential alternative for conservation. African Journal of Plant Sciences 7(10):448-467. https://doi.org/10.5897/AJPS2013.1031

Pellegrino G, Masucchio A, Noce ME, Palermo AM, Widmer A (2005). Reproductive versus floral isolation among morphologically similar Serapias L. Species (Orchidaceae). Journal of Heredity 96(1):15-23. https://doi.org/10.1093/jhered/esi006

Ponert J, Vosolsebe S, Kmecova K, Lipavska H (2011). European orchid cultivation-from seed to mature plant. European Journal of Environmental Sciences 1(2):95-107. https://doi.org/10.14712/23361964.2015.52

Renz J, Taubenheim G (1984). Orchidaceae. In: Davis PH (Ed). The Flora of Turkey and the East Aegean Islands, Vol. 8. Edinburgh University Press, Edinburgh.

Saglam M (2013). The estimation with canonical correlation analysis of relationships between physical and chemical properties in entisol and inceptisol soils. Ziraat Fakültesi Dergisi-Süleyman Demirel Üniversitesi 8(2):66-79. https://dergipark.org.tr/tr/pub/sduzfd/issue/29593/317502

Sandal G (2009). Eastern Mediterranean region and grows orchids with the threat of habitat characteristics to investigate factors. PhD Dissertation, Cukurova University, Graduate School of Sciences, Adana.

Sevgi E, Altundag E, Kara O, Sevgi O, Tecimen HB, Bolat I (2012). Relations between morphological characteristics and community structure of Serapias bergonii E.G. Camus species in Çanakkale-Biga. In: Turkey II. Orchid and Salep Workshop Proceedings Book, 157-171, Aegean Agricultural Research Institue, No: 153, Meta Publications, Izmir.

Sherry A, Henson RK (2005). Conducting and interpreting canonical correlations analysis in personality research: a user-friendly primer. Journal of Personality Assessment 84(1):37-48. https://doi.org/10.1207/s15327752jpa8401_09

Soganci K (2017). Determination of canonic correlation among characteristics of local dry beans (Phaseolus vulgaris L.) genotypes collected from Middle Kızılırmak Valley. Master's Thesis. Ahi Evran University, Institute of Science. Kirsehir.

Swarts ND, Dixon KW (2009). Terrestrial orchid conservation in the age of extinction. Annals of Botany 104(3):543-556. https://doi.org/10.1093/aob/mcp025

Tatiya A, Kalaskar M, Patil Y, Surana S (2018). Chemical analysis, nutritional content and antioxidant property of Eulophia herbacea Lindl. tubers: a medicinally versatile Indian tribal nutritional food supplement. Indian Journal of Traditional Knowledge 17(1):141-147.

Temurtas A (2016). Canonical correlation analysis. In: Multivariate statistics for all. Guzeller CO (Ed). Maya Academy Publication, Ankara, pp 101-112.

Turgay O, Cinar I (2017). Salep: the name of the plant, powder, hot beverage, food ingredient. KSU Journal of Engineering Sciences 20(3):68-71. https://doi.org/10.17780/ksujes.341382

Tutar M, Sari AO, Cicek F, Yildiz O (2012). Main orchids collected for salep from Aegean region. In: Turkey II. Orchid and Salep Workshop Proceedings Book, Aegean Agricultural Research Institue, No: 153, Meta Publications, Izmir, pp 145156.

Utami ESW, Hariyanto S, Manuhara YSW (2017). In vitro propagation of the endangered medicinal orchid, Dendrobium lasianthera J.J.Sm through mature seed culture. Asian Pacific Journal of Tropical Biomedicine 7(5):406-410. https://doi.org/10.1016/j.apjtb.2017.01.011

Uzun S (1996). The quantitative effects of temperature and light environment on the growth, development and yield of tomato (Lycopersicon esculentum Mill.) and aubergine (Solanum melongena L.). Master Thesis, The University of Reading, Reading, UK.

Vainionpaa J, Kervinen R, Prado M, Laurila E, Kari M, Mustonen L, Ahvenainen R (2000). Exploration of storage and process tolerance of different potato cultivars using principal component and canonical correlation analyses. Journal of Food Engineering 44(1):47-61. https://doi.org/10.1016/S0260-8774(99)00164-8

Venhuis C, Venhuis P, Oostermeijer JGB, van Tienderen PH (2007). Morphological systematics of Serapias L. (Orchidaceae) in southwest Europe. Plant Systematics and Evolution 265(3-4):165-177. https://doi.org/10.1007/s00606-007-0519-0

Warghat AR, Bajpai PK, Srivastava RB, Chaurasia OP, Chauhan RS, Sood H (2014). In vitro protocorm development and mass multiplication of an endangered orchid, Dactylorhiza hatagire. Turkish Journal of Botany 38:737-746. https://doi.org/10.3906/bot-1308-48

Xian-Li X, Ke-Ming M, Bo-Jie F, Cheng-Jun S, Wen L (2008). Relationships between vegetation and topography in a dry warm river valley SW Chin. Catena 75:138-145.

Yaman K (2013). Regulations relating to the salep and its trade in Turkish official gazette archives from 1920 to the present. Journal of History Culture and Art Research 2(1):172-180. 
Yerkin D, Temizel KE (2018). The effects of sodic water applications at different levels on the leaf area and leaf area estimation of bean plants. Black Sea Journal of Agriculture 1(3):70-75.

OPEN ACCESS

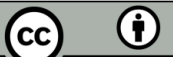

The journal offers free, immediate, and unrestricted access to peer-reviewed research and scholarly work. Users are allowed to read, download, copy, distribute, print, search, or link to the full texts of the articles, or use them for any other lawful purpose, without asking prior permission from the publisher or the author.

License - Papers published in Notulae Botanicae Horti Agrobotanici Cluj-Napoca are Open-Access, distributed under the terms and conditions of the Creative Commons Attribution (CC BY) License. (C) Articles by the authors; UASVM, Cluj-Napoca, Romania. The journal allows the author(s) to hold the copyright/to retain publishing rights without restriction. 